\section{Gene therapy guidelines}

The board of directors of the American Society of Gene Therapy (ASGT; Milwaukee, WI) has voted to approve a policy stating that investigators and team members involved in gene therapy clinical trials should not have any financial stake in the outcome of those trials. According to ASGT President Savio Woo, "This policy is a significant step forward in addressing the safety and interests of the many patients who volunteer in such trials." The policy notes that such ethical standards should apply to all medical research, and states that "clinical investigators must be able to design and carry out clinical research studies in an objective and unbiased manner, free from conflicts caused by significant financial involvement with the commercial sponsors of the study." However, because ASGT is a nonprofit educational and scientific society and not a regulatory body, the guidelines are strictly voluntary.

\section{$J G$}

\section{Structural genomics deal}

The governments of Japan and the US are planning to launch an international collaborative project to elucidate the structure of proteins. Hirofumi Nakasone, director-general of Japan's Science and Technology Agency (Tokyo), and Neal Lane, scientific advisor to US President Bill Clinton, agreed in May to create common procedural guidelines for an international structural genomics project comparable to the Human Genome Project. The agreement follows a meeting between international scientists from the US, France, Germany, UK, Israel, and Japan that was held in April at the Sanger Centre (Cambridge, UK) to discuss ground rules for a structural genomics collaboration. The discussions focused on policies related to data release and intellectual property, but talks on scientific approaches, which differ widely among research groups, were left out. Many hope the international conference on structural genomics, to be held in November at Japan's Genomic Science Center in Yokohama, will become a forum for detailed discussions on scientific issues, the time scale and membership of the project, and-most contentious of allintellectual property.

Business and regulatory news briefs written by Alan Dove, Jeffrey Fox, Julie Grisham, John Hodgson, KS Jayaraman, Sabine Louët, Eric Niiler, Debra Robertson, and Asako Saegusa.

\section{Ruling favors Amgen}

In late April, the US District Court of Massachusetts ruled that the erythropoietin (EPO) produced and used by Transkaryotic Therapies (TKT; Cambridge, MA) and its partner Aventis Pharma (Frankfurt) is covered by a claim in one of Amgen's (Thousand Oaks, CA) five EPO patents. After hearing Amgen argue that the "pharmaceutical composition" of TKT's 165-amino acid EPO was chemically and functionally indistinguishable from its own 166-amino acid version, chief Judge William Young made a summary judgment of infringement of Amgen's US Patent $5,555,422$. Although the ruling limits TKT's defense strategy with respect to that patent (Nat. Biotechnol. 18, 483), issues of patent infringement, validity, and enforcement for the other four patents are still being argued at the trial that began in mid-May.

$D R$

\section{Japan's cloning law fails}

Japan's cloning regulations took an unexpected turn in April when draft legislation prohibiting the use of cloning techniques for human reproductive purposes failed to pass Parliament, despite having gained initial approval from the cabinet and the ruling Liberal Democratic Party. The Democratic Party of Japan (DPJ), the main opposition party, rejected the new bill because it considers it to be full of loopholes that could "effectively open a back door for human cloning research." Although the draft legislation bans the reimplantation of human clones, chimeras, and hybrid embryos into human or animal uteri, some forms of nuclear transfer would be regulated only by means of guidelines because of their potential applications for human embryo and stem-cell research (Nat. Biotechnol. 18, 366). The DPJ argues that the new law should cover all reproductive techniques, as is the case with human cloning regulations in the UK and France.

$A S$

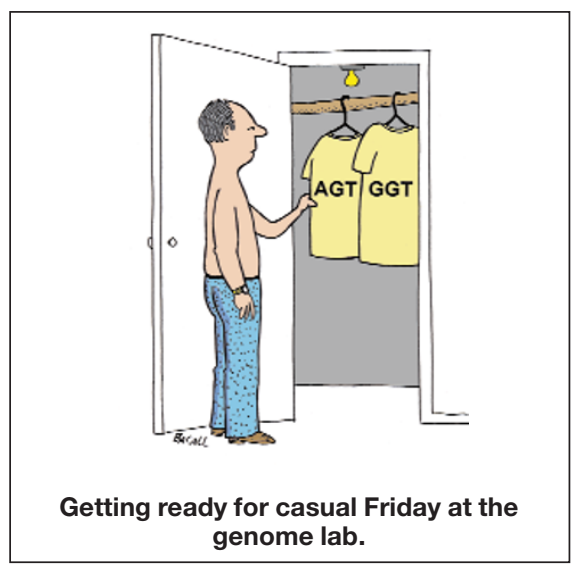

\section{GMO roundup}

- Back pain specialists in the US are the latest health professional group to take a pop at genetically modified foods. An article in the Journal of the American Chiropractic Association warns: "Some hazards from the GE process could directly impact patients who ingest the food" and adds, rather fluffily, that "other hazards are indirect, operating through pollution of other food species or through unintended effects on local and global ecosystems." The article "reveals" a number of hazards of genetically engineered foods including the presence of herbicide resistance genes that "guarantees that humans who ingest the foods will be exposed to herbicides with a litany of adverse health effects." The article stops short of indicating precisely what new economic factors will encourage farmers to squander their profits by coating their crops with an unnecessarily generous layer of herbicide, and neither does it disclose which part of the human photosynthetic apparatus the herbicides will affect. Unsurprisingly, the article also polishes off the old allergenicity chestnut (the food never got anywhere near the consumer, guys) and it points to toxicity effects originating with crops that produce "bacillicus [sic] thuringiensis toxins." The article seems to have been written by people who, despite being well schooled in human anatomy, do not know their "bacillicus" from their elbow.

- At last, the GM food debate is maturing. In April, a protest group called the Biotic Baking Brigade provided new evidence of the hazards of being publicly pro-biotechnology by projecting a volley of sweet pastries in the face of Martina McClaughlin, director of biotechnology at the University of California, Davis. UC Davis has been a particular target for the direct antibiotechnology action because of its leading position in plant biotechnology and its associations with a number of commercial companies in the field. The actions of Biotic Baking Brigade agents-Chocolate Silk, Key Lime, and Raspberry-truly helped focus world attention on the real solutions to world hunger-the delivery of copious baked confectioneries to subsistence farmers and the landless in the developing world.

$J H$ 